\title{
The Effect of Remittances on Education in Togo
}

\author{
Kokouvi Kunalè Mawuena1, Mawussé Komlagan Nézan Okey² \\ ${ }^{1}$ Center for Research and Training in Economics and Management (CERFEG), Faculty of Economics and Management, \\ University of Lomé, Lomé, Togo \\ ${ }^{2}$ University of Lomé, Lomé, Togo \\ Email: syl.mawuena@gmail.com,mawusseo2000@gmail.com
}

How to cite this paper: Mawuena, K. K., \& Okey, M. K. N. (2021). The Effect of Remittances on Education in Togo. Theoretical Economics Letters, 11, 1293-1311. https://doi.org/10.4236/tel.2021.116081

Received: November 4, 2021

Accepted: December 27, 2021

Published: December 30, 2021

Copyright $\odot 2021$ by author(s) and Scientific Research Publishing Inc. This work is licensed under the Creative Commons Attribution International License (CC BY 4.0).

http://creativecommons.org/licenses/by/4.0/

(c) (i) Open Access

\begin{abstract}
Togo is not exempt from migration phenomenon in the last few years, as the statistics show that it experiences a galloping migratory flow. This trend in migratory flow leads us to question the possible repercussions on the daily lives of households. This article analyses the effect of migrants' remittances on the education of recipient households with econometric analysis using a binary logit model with instrumental variable. The estimations results show that remittances from migrants as well as income increase the level of education of recipients in countries. The results have also made it possible to note that access to electricity significantly improves the level of education of the household's members. Suggestions are made to education decision-makers in the perspective of strengthening the education system in Togo and facilitating the procedures of remittances to Togo.
\end{abstract}

\section{Keywords}

Remittances, Education, Migration, Togo

\section{Introduction}

Despite the risks that migration presents nowadays, it is for many people in middle- and low-income countries an opportunity especially through remittances from migrants. These remittances are the way for resident households to smooth their spending from basic needs. In recent years, remittances exceed not only foreign direct investment (FDI) but also export earnings and foreign aid. The purpose of this paper is to analyse the effects of remittances on education in Togo.

In 2000 The Millennium Development Goals (MDGs) recognize in education an important way for individuals to realize their capacity and consequently, priority is given to the completion of primary education. Following these, the 
fourth goal of the Sustainable Development Goals reiterates the importance of education and aims to ensure access for all to equitable, free and quality education through all stages of life, including the elimination of gender and income disparities. It also focuses on the acquisition of fundamental and higher-level skills to live in a sustainable society as well as the construction and improvement of educational infrastructure. Aware of its importance in development, education defined according to Emil Durkheim as "the action exercised by the adult generations on those who are not yet ripe for social life" aims to arouse and develop in the child a certain number of physical, intellectual and mental states that require of him and the political society as a whole and the social environment for which he is particularly destined.

$71 \%$ of the 62.2 million out-of-school children of primary school age and 59\% of the 60.7 million out-of-school children of lower secondary school age in the world in 2016 live in developing countries (World Bank, 2020). Children from the poorest households, who live in rural areas and in countries affected by fragility and conflict, are even more likely to be left behind, as are girls in many countries. Like other developing countries, in the WAEMU area, the primary school completion rate is unsatisfactory over the period 2015-2018 (World Bank, 2020). With a completion rate of $89 \%$, the Togolese State has made many efforts in recent years to improve schooling conditions. It is followed by Côte d'Ivoire (71.6\%), Burkina Faso (65\%), Senegal (57\%) and Mali (49.6\%).

In Togo, enrolment improved at almost all levels of education between 2011 and 2018. Coverage of pre-school education more than doubled over the same period. In 2018, 34\% of Togolese children were pre-schooled compared to only $14 \%$ in 2011; while $91 \%$ of children complete primary school in 2018 compared to 2011 when the rate was $76 \%$ (UNESCO, 2020). The priority for education remains high. In 2017, the total state budget allocated to education was $19 \%$. However, this budgetary priority is mainly driven by current expenditure, which represents $24.6 \%$ of the State's operating budget against only $1.9 \%$ of the State's investment budget. Despite the low purchasing power of Togolese, in 2015 households spent almost 77,000 francs per student in school. This expenditure is slightly increasing, more precisely by $18 \%$, compared to its level in 2011 and the poorest are those who suffer the most.

However, worldwide remittances received from migrant workers have more than quadrupled between 2000 and 2011, from CFAF 323.1 billion to CFAF 1353 billion. Relative to GDP, they rose from $1.7 \%$ in 2000 to $3.6 \%$ in 2011 . Over this period, they represented on average $3.7 \%$ of the Union's GDP. This proportion varies from $0.9 \%$ in Côte d'Ivoire to $8.8 \%$ in Niger. It is estimated at $2.9 \%$ in Benin, $1.3 \%$ in Burkina Faso, 3.9\% in Guinea-Bissau, 3.4\% in Mali and $7.3 \%$ in Senegal. Togo is to date, the country receiving more remittances from migrants relative to GDP and stands at $8.8 \%$.

As in other countries of the West African subregion, the evolution of migrants' remittances has also been notable in recent years in Togo. Over the period 2010 
to 2019, this overall evolution of the amounts transferred is marked by a steady growth from $\$ 337$ million to $\$ 510$ million, an increase of $51 \%$. In addition, in Mali, remittances increased from $\$ 473$ million to $\$ 987$ million over the same period, an increase of $109 \%$. Although Mali receives more remittances from migrants than Togo, it is clear that the share of remittances devoted to human capital formation is still low compared to Togo (5\% in Mali against 6\% in Togo).

Indeed, migrants' remittances can affect education through at least two channels: 1) relaxation of financial conditions, 2) human capital in general and good health in particular. In view of these findings, the question arises as to what is the effect of migrants' remittances on education in Togo? The objective we set ourselves to answer this question is to analyze the effect of migrant remittances on education in Togo. To achieve this goal we adopt a methodology that consists of estimating a binary logit model with data from the Unified Questionnaire of Basic Indicators of Well-being (QUIBB) survey among 2367 urban and rural households in Togo.

The contribution of this work lies in the fact that survey data are mobilized to address the issue at the micro level unlike previous work on Togo which had addressed the subject at the macroeconomic level.

The rest of the paper is organized as follows. The first section presents previous work on the relationship between remittances and education in developing countries, the second section discusses the methodological approach of the study. The third section presents the results of the empirical analysis and the last section (5) concludes.

\section{Literature Review}

The relationship between migrant remittances and education in countries of origin has been addressed by several theoretical and empirical studies. Previous work has shown that remittances that ease liquidity constraints can have a positive impact on human capital formation (Askarov \& Duucouliagos, 2020; Ballo \& Alphonsine, 2018; Chea \& Wongboonsin, 2020; García Nájera \& Cuecuecha Mendoza, 2020; Medina \& Cardona, 2010; Pickbourn, 2016).

As part of the work on the reasons that motive migrants to remit, the theory of the implicit co-insurance contract implies that the family invests in the education and subsistence of the migrant in their home country and will eventually be able to finance the costs of his future migration. In return, the migrant must support the family by sending part of their income earned in the host country. These new resources will enable the remaining family to cope with possible negative shocks (illness, unemployment, poor harvest, etc.) and to undertake new projects. In a second step, the migrant finances the costs of possible migration of other family members (Amuedo-Dorantes et al., 2006; Gubert, 2002; Calero et al., 2009; Agarwal \& Horowitz, 2002).

These resources constitute a kind of private insurance that covers the socio-economic, health and environmental risks incurred by the migrant's native 
society. Furthermore, Calero et al. (2009) suggest that the occurrence of a negative income shock (death and illness of a family member, drought, frost period, natural disaster, etc.) is associated with greater participation of children in the labour market, while migrant remittances are mainly used by households in financing children's education. If this is the case, the authors believe that in the short term, migrant remittances serve as insurance by maintaining children's schooling. They help households ease liquidity constraints, stabilize consumption and invest in production.

Compared to empirical work, García Nájera and Cuecuecha Mendoza (2020) present in their article the results of a study on the impact of international remittances on investment in education in the Mexican city of Caltimacán, Hidalgo, Mexico, a community characterized by legal migration through temporary employment contracts. The estimates use instrumental variables based on job creation in U.S. states where migrants worked between 2010 and 2016. The results of their work show that the proportion of expenditure on education is higher among households that receive transfers than among households that do not. However, this effect disappears when household spending and wealth are introduced into the model. These results confirm that investments in the education of the inhabitants of Caltimacán are confronted with credit constraints, which in turn are diminished by the receipt of remittances.

Mansuri (2006) and Calero et al. (2009) clearly proves that income poverty tops the list in the explanatory factors of dropping out of school. It often forces parents to drop their children out of school and put them to work. In order to mitigate the effects of these financial constraints on the household, some studies suggest that migrant remittances can influence parents' decision to work and/or invest in their children's education. Some socio-economic characteristics of the migrant household, such as the gender of the child and the area of residence, have an influence on the effect of remittances on children's work and education. Studies by Mansuri (2006) and Boutin (2011) show that these funds significantly reduce child labour of both genders. Others, on the other hand, prove that these funds have no influence on the work of male children (Acosta, 2006) or, on the contrary, influence only that of boys (Yang, 2008) or girls (Calero et al., 2009). The impact of transfers on reducing labour supply is relatively large for girls and children living in rural areas.

In order to see the impact of parental education on the demand for education and on the supply of child labour following remittances, Hanson and Woodruff (2003) and Gang et al. (2008) reveal that educated parents tend to encourage their children to continue their education, rather than bringing them into the workforce at an early age in order to smooth out parents' income fluctuations. Rapoport and Docquier (2005) and Adams and Cuecuecha (2010) show that, in particular, the effect of parental absence on children's education is a crucial issue. While remittances received from a migrated parent help meet short-term consumption and the long-term physical and human investment needs of 
households, parental absence leads to family disruptions. Studies also show that children left behind are employed to close the household work gap resulting from the absence of adult members of the household. The latter finds that the extent of the disruption, especially for boys aged 12 to 15 , increases by well over 50 percentage points if Mexican migrants are fathers. Mckenzie et al. (2011), rely on human capital theory to demonstrate the overall impact of migration or remittances. These transfers add value to the resources of recipient households, improving the educational achievement of the children left behind. On the other hand, family disturbances resulting from parental absence and increasing the non-financial costs of education hinder this achievement.

\section{Methodology for Empirical Analysis of Effects on Education}

Several estimation methods have been addressed in studies on the relationship between remittances and human capital. In addition, the adoption of an econometric method for estimating these effects has often encountered difficulties. In addition, these estimates most often involve using micro data on individuals to explain and predict their interactions with several alternatives (Amemiya, 1981; Maddala, 1983; Gertler \& Glewwe, 1989; Gouriéroux \& Monfort, 1989). Other studies considering the relationships between the determinants affecting schooling through remittances have used correlation analysis. This approach is limited by the fact that simple correlations between a few variables can be highly influenced by other variables so that each contains the false effects of the other variables (Cimmyt, 1993). Econometric analyses using the ordinary least squares method have often been used. The problems of heteroscedasticity generated by this approach have highlighted the invalidity of the tests carried out on the basis of these methods (Gouriéroux \& Monfort, 1989). Following these successive methods, our empirical analysis focuses on the probability of going to school given the receipt of remittances. To do this, we will use logit estimation and instrumental variable (IV) logit estimation to also take into account the problem of potential endogeneity of migrant remittances.

In this research, in view of the binary choice facing the individual, we estimate the econometric model through a logit regression with intrusive variables. This approach is fundamentally inspired by Raut and Tanaka (2018) which drew its source from those of Matano and Ramos (2013) on the one hand, and Mansour et al. (2011) on the other hand.

The estimation model used in this section is largely based on the work of Raut and Tanaka (2018) who drew inspiration from Mckenzie et al. (2011) under human capital theory demonstrating the effects of migrant remittances on the educational performance of individuals in their home countries. These theoretical developments were also empirically implemented later in the work of Matano and Ramos (2013) who were inspired by Mansour et al. (2011). For this purpose, we use a binary logit model because of the schooling status of individuals in the 
household.

$$
\begin{gathered}
P(E \mid X)=\frac{\exp (\alpha+\beta X)}{1-\exp (\alpha+\beta X)} \\
\operatorname{Pr}\left(E=1 \mid X_{i}\right)=\beta_{0}+\beta X_{i}+\varepsilon_{i} \\
Y^{*}=\beta_{0}+\beta X_{i}+\varepsilon_{i}
\end{gathered}
$$

where $Y^{*}$ represents the probability of being educated by individuals in a household;

$X_{i}$ represents all the explanatory variables of the schooling of individuals;

$\beta_{0}$ and $\beta$, a vector of parameters to be estimated; $\varepsilon_{i}$, the term random error.

$Y^{*}$ takes the value 1 if the individual is in school $\left(Y^{*}>0\right)$ and 0 if the individual is not $\left(Y^{*}<0\right)$.

$P($ education $=1 \mid X)$

$=\beta_{0}+\beta_{1}$ transfert migrant $+\beta_{2}$ Age $+\beta_{3}$ Age $2+\beta_{4}$ Sexe

$+\beta_{5}$ Situation Matrimoniale $+\beta_{6}$ Taille menage $+\beta_{7}$ Possession maison

$+\beta_{8}$ Pelec $+\beta_{9}$ Quintile de richesse $+\beta_{10}$ Maison Primaire

$+\beta_{11}$ Maison Secondaire $+\beta_{12}$ Residence $+\varepsilon_{i}$

Taking into account the problem of endogeneity in migrants' remittance has been mentioned in several studies (López-Córdova \& Olmedo 2006; McKenzie \& Rapoport, 2006; Gang et al., 2008, etc.). The use of externally sourced remittances from migrants to explain the level of education attained by individuals could lead to potential endogeneity biases. In other words, these remittances can be correlated with the error term in the functional specification of the model or some variables not taken into account by the model can influence the remittances of Togolese migrants. Among other things, remittances can be used as a pretext to finance children's school fees, and our basic equation explains schooling by, among other things, migrant remittances. We then face a two-way causality leading us to resort to the use of instrumental variables. The literature review highlights the distance between the child's home and school as a reason for remittances. To take into account the potential endogeneity bias in migrant transfers and the distance between the place of residence and schools, we will carry out endogeneity tests using the Rivers-Vuong (1988). Two steps are suggested by the latter in order to carry out the tests.

First step: estimate the endogenous variable "migrant remittances" by regressing it over all independent variables (instruments and explanatory variables);

Second step: introduce the residue from the regression in the first step into the parent equation explaining education. The nullity of the residue coefficient is qualified thanks to the student test.

\section{- Choice and relevance of instruments}

The results from our estimates by not taking into account the potential endogeneity bias can be biased if certain exogenous variables are also endogenous, 
especially if they are variables of interest. To overcome the problem of endogeneity that we face, we take into account instrumental variables that are supposed to act on migrant remittances but not on education. In the context of this study, two types of instruments are distinguished for this purpose: (i) relevant instruments that we cannot use in the context of our study due to their unavailability; (ii) instruments that exist in the literature and some of which are, from our point of view, unconvincing.

The first category of instruments takes into account potential shocks impacting household income (Gang et al., 2008). The instruments suggested by McKenzie and Rapoport (2006) fall into the second category of instruments. One example is the history of migration networks that can continue to influence the migration decisions of household members. In the context of Togo, the migration history has probably not influenced the costs of transfers, which will in turn affect the transfer of migrants.

In this second category of instruments, we also use the instrumental variable proposed by De Vreyer et al. (2010), i.e. the number of children of all adult family members who are neither children nor grandchildren of the head of household receiving transfers. We think that in the context of our study, the family environment could influence parents' decision to send their children to school Bouoiyour et al. (2018). This instrument has been tested to control its influence on migrant remittances. In addition to this instrument, exceptional family events (weddings, traditional festivals, funerals, Mecca-hajj, etc.) will allow the family to gather, which requires an increase in the flow of migrants' remittances.

\section{- Procedure}

The use of instrumental variables requires initially carrying out validation tests of the instruments. In principle, these instruments should be correlated with the presumed endogenous explanatory variable but not with the model-dependent variable. The coefficients of the instrumental variables taken into account are then estimated in a model where the so-called endogenous explanatory variable is considered as a dependent variable. These coefficients must be significantly different from zero. Following this test, we test the overidentification of the instrumental variables. The residue from the estimation of the equation taking into account the instrumental variables is retrieved and introduced into the initial equation. The latter should not be correlated with instruments and therefore education. The Fisher test of the overall nullity of coefficients is used in this test.

The null hypothesis cannot be rejected if the $N^{*} R 2$ statistic is less than the theoretical value. As soon as the instruments are valid, we estimate again the effect of remittances on education by taking into account valid instrumental variables.

\section{- Data and description of variables}

\section{- Data Sources}

This research uses data from the Unified Questionnaire of Basic Indicators of Well-being (QUIBB) survey conducted in Togo in 2015. The survey was devel- 
oped and conducted by the National Institute of Statistics and Economic and Demographic Studies (INSEED). It was financed by the Togolese government. The survey collected comprehensive information that is not usually captured by traditional household surveys and is nationally representative. Two instruments were used in the survey: a basic income-expenditure questionnaire and a household-individual questionnaire. The sample size of the basic questionnaire was 2367 urban and rural households in Togo.

- The household questionnaire is composed of 16 sections that are described: Information on the questionnaire, List of household members, Education, Health, Work, Employment carried out in the last 12 months, Possessions of plots of land in the household, Possessions of livestock in the household, Non-agricultural enterprises: Existence of non-agricultural enterprises, Nonagricultural enterprises: Characteristics of non-agricultural enterprises, Food security, Supplement on food consumption, Shocks and survival strategies, Gender, Habitat characteristics, Subjective poverty.

- The questionnaire of the Household Income and Expenditure module is composed of 6 sections which are described: Agricultural production, Durable goods, Self-consumption, Current expenditure, Retrospective expenditure, Household income.

\section{Definition and descriptive analysis of variables Setting variables}

In this section, we will present the descriptive statistics of the variables used in our research. To this end, it can be seen that the average age of individuals is about 26 years. This age corresponds to the age group in which individuals remain able to increase their level of education.

\section{- Choice of the dependent variable}

The objective of our study is to assess the chances for a member of household to be educated, and to extend his studies, depending on whether or not his family receives remittances from abroad. Starting from the work of (Bouoiyour \& Miftah, 2014) on the one hand and (Raut \& Tanaka, 2018) on the other hand, we consider in the context of this research the education of a household member as the probability of "school attendance at the time of the survey" ( 1 if schooled and 0 for if not in school).

\section{- Choice of explanatory variables}

A relatively extensive body of empirical literature exists on the analysis of factors influencing school attendance by household members in developing countries. However, this literature has failed to take into account the theories developed by the new migration economy with regard to education. Few of this work have integrated international migration and financial transfers into their development. For the limited research that has done so, family members' access to education would depend on the socio-economic characteristics of the family remaining in the home country (e.g. the level of wealth of the parents and the possession of durable goods), the amount of remittances from abroad and the per- 
sonal characteristics of the migrants' household of origin. However, in developing countries including Togo, parents are the biggest financiers of their children's education. This trial then takes into account as independent variables: characteristics related to the living environment of the recipient household member, family characteristics, and socioeconomic characteristics (Table 1).

\section{Results and Interpretation of the Analysis of the Effect of Remittances on Education}

\section{- Descriptive analysis.}

Table one presents the variables considered in this article and how each of them has been measured. these variables are split into several categories, such as individual characteristics, household and habitat characteristics in addition to sustainable assets and household wealth.

The analysis of the Pearson correlation matrix allows us to identify probable correlations between the different variables taken into account in our estimation

Table 1. Description of variables.

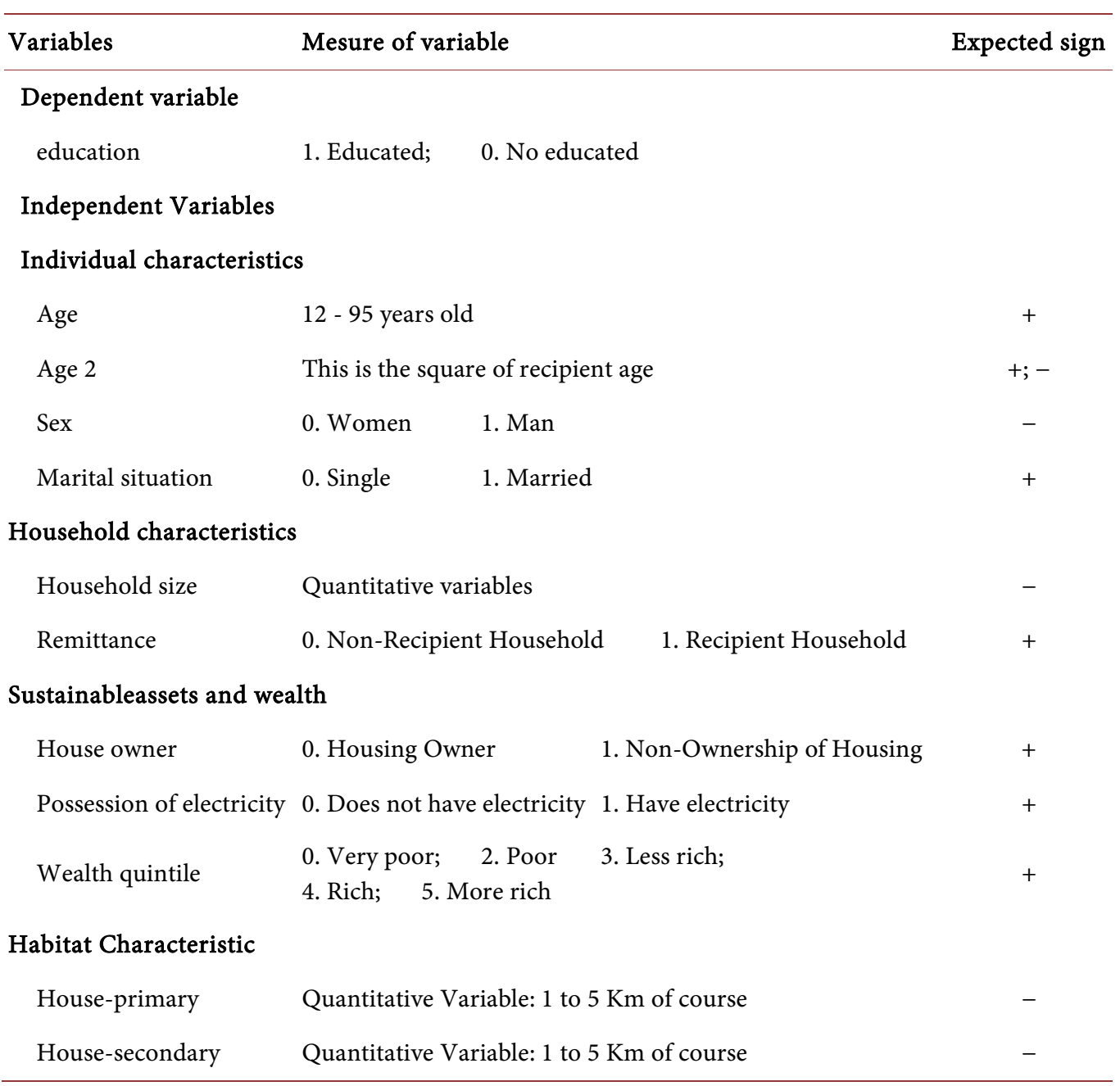

Source: Authors. 
model. For this purpose, variables such as marital status, age of the head of household (Age), gender of the head of household have a high level of correlation with the dependent variable "level of education of household members" living in recipient households with a significance threshold of $5 \%$ (respectively $0.661 ; 0.203 ; 0.443)$. However, this matrix shows that remittances received from migrants have a low level of correlation with the education of members of the recipient household (0.203) (Table 2 ).

- Analysis and interpretation of econometric results related to the effect of remittances on education

Econometric estimates have made it possible to highlight among the variables that have caught our attention and that have been integrated into our econometric model, the factors that explain the level of education attained by individuals in households receiving migrants' funds. These show that the coefficients are most significant at the threshold of $1 \%, 5 \%$ and $10 \%$.

The relationship between remittances and human capital in home countries remains an important issue. To this end, the results of our estimates show that remittances increase the likelihood of education in the home countries. In Togo, receiving remittances from migrants does not significantly increase the probability of education by 0.016 . This non-significant increase in educational attainment is explained by the fact that remittances are part of related expenditures that do not directly affect the education of household members.

Our results showed that the probability of studying increases by 0.070 when

Table 2. Matrix of the correlation of the variables forming the education.

\begin{tabular}{|c|c|c|c|c|c|c|c|c|c|c|c|c|c|}
\hline Variables & -1 & -2 & -3 & -4 & -5 & -6 & -7 & -8 & -9 & -10 & -11 & -12 & -13 \\
\hline (1) Education & 1.000 & & & & & & & & & & & & \\
\hline (2) Transfers & $-0.203^{\star}$ & 1.000 & & & & & & & & & & & \\
\hline (3) Age & $-0.661^{\star}$ & $0.021^{\star}$ & 1.000 & & & & & & & & & & \\
\hline (4) Age2 & $-0.580^{\star}$ & $-0.029^{*}$ & $0.966^{\star}$ & 1.000 & & & & & & & & & \\
\hline (5) Sex & $0.233^{*}$ & $-0.188^{\star}$ & $-0.289^{*}$ & $-0.323^{*}$ & 1.000 & & & & & & & & \\
\hline (6) Residence & $-0.155^{\star}$ & $0.156^{\star}$ & $-0.190^{*}$ & $-0.245^{\star}$ & $0.041^{\star}$ & 1.000 & & & & & & & \\
\hline (7) Marital situation & $-0.443^{*}$ & $-0.131^{\star}$ & $0.530^{\star}$ & $0.463^{\star}$ & $-0.317^{\star}$ & $-0.127^{\star}$ & 1.000 & & & & & & \\
\hline (8) Quintile & $0.038^{*}$ & $0.147^{\star}$ & -0.006 & -0.004 & $0.103^{*}$ & $0.364^{*}$ & $0.144^{*}$ & 1.000 & & & & & \\
\hline (9) Household size & $0.188^{*}$ & $0.019^{*}$ & $0.106^{*}$ & $0.128^{\star}$ & $-0.120^{*}$ & $-0.217^{\star}$ & $0.050^{*}$ & $-0.067^{*}$ & 1.000 & & & & \\
\hline (10) House-primary & $-0.217^{\star}$ & $0.139^{\star}$ & $0.330^{*}$ & $0.296^{*}$ & $-0.181^{\star}$ & $-0.280^{\star}$ & $0.192^{\star}$ & $-0.164^{\star}$ & $-0.036^{\star}$ & +1.000 & & & \\
\hline (11) House-secondary & $0.047^{\star}$ & $-0.269^{*}$ & $0.108^{\star}$ & $0.124^{\star}$ & $-0.052^{\star}$ & $-0.481^{\star}$ & $0.082^{\star}$ & $-0.466^{*}$ & $0.146^{*}$ & $0.306^{*}$ & 1.000 & & \\
\hline (12) House & $0.023^{*}$ & $-0.179^{*}$ & $0.125^{*}$ & $0.150^{*}$ & $0.092^{*}$ & $-0.668^{\star}$ & -0.001 & $-0.483^{*}$ & $0.099^{*}$ & $0.236^{*}$ & $0.345^{\star}$ & 1000 & \\
\hline $\begin{array}{l}\text { (13) Electricity } \\
\text { possession }\end{array}$ & $-0.136^{\star}$ & $0.208^{\star}$ & 0.006 & $-0.081^{\star}$ & $0.039^{*}$ & $0.666^{*}$ & $-0.072^{*}$ & $0.197^{\star}$ & $-0.179^{\star}$ & ${ }^{+} 0.012^{\star}$ & $-0.327^{*}$ & $-0.359^{*}$ & 1.000 \\
\hline
\end{tabular}

*Shows significance at the 0.05 level; Source: Author's calculation from QUIBB 2015 survey data. 
the member of the household to be educated is a boy and remains consistent with the results of the work of Yang (2008). This result is explained by the fact that in the African context in general and Togolese in particular, through remittances from migrants, young boys are led to take over from the family as leaders and therefore should make greater use of the transferred funds for their education.

In contrast, the probability of studying decreases in convexly with the age of household members receiving transfers. As for the distance between the house and the nearest primary school as well as the nearest secondary school, the estimates are not significant. As for the household wealth level index, the estimates are only significant for the poor, the rich and the richer. These increase the probability of studying by 0.18 respectively; $0.316 ; 0.326$. These results can be answered by the high cost of education except for the free primary school introduced since 2008 in Togo.

According to the regression results, marital status is a key factor in the education of individuals. Our estimates show that being married decreases with a significance threshold of $1 \%$ the probability of dating recipient members of 0.28 . This result may be due to the fact that in developing countries such as Togo, being married further complicates access to education since once married, men and women must perform tasks that give them various trajectories other than increasing their level of education. The wealth of a household is correlated with the level of education of the individual. Indeed, if the wealth quintile remains positive, the probability that the individual will increase his or her level of education also increases. In particular, this probability increases by 0.019 with the level of wealth of the household.

The results of the estimates also show us a correlation between the possession of durable goods and education. Considering electricity, the probability of education increases by 0.022 with electricity possession (Raut \& Tanaka, 2018). This finding remains consistent with the findings of de Haas (2006) findings that international migrant households invest more than others in housing, agriculture and other family businesses.

In addition, in order to specify the effect of migrants' remittances on education taking into account gender, the results show that remittances significantly attenuate male education. With regard to women's education, remittances have a negative but not significant effect. These results are counterintuitive and do not corroborate the results of the work of some authors (Calero et al., 2009; Hanson \& Woodruff, 2003; Mansuri, 2006). This could be explained by the fact that in low-income countries such as Togo, the collection of remittances is much more directed towards micro-entrepreneurial investment expenditures and therefore will not be able to contribute to the accumulation of human capital (Woodruff \& Zenteno, 2001) (Table 3 \& Table 4).

\section{Robustness of estimates of the effect of remittances on education}

Finally to ensure the robustness of the results obtained through logit regression, in this section, we have used estimation by instrumental variables and the 
Table 3. Logit estimation with marginal effects of remittance on education.

\begin{tabular}{|c|c|c|}
\hline VARIABLES & Logit regression & Marginal effects \\
\hline \multirow[t]{2}{*}{ Migrant transfer } & 0.129 & 0.016 \\
\hline & $(0.229)$ & $(0.030)$ \\
\hline \multirow[t]{2}{*}{ Age } & $-0.473^{\star \star *}$ & $-0.62^{* * *}$ \\
\hline & $(0.0184)$ & $(0.004)$ \\
\hline \multirow[t]{2}{*}{ Age2 } & $0.00394^{* * *}$ & $0.001^{* * *}$ \\
\hline & $(0.000204)$ & $(0.000127)$ \\
\hline \multicolumn{3}{|l|}{ Female (Reference) } \\
\hline \multirow[t]{2}{*}{ Sexe } & $0.535^{\star * *}$ & $0.070^{* * *}$ \\
\hline & $(0.108)$ & $(0.015)$ \\
\hline \multicolumn{3}{|l|}{ Urban (Reference) } \\
\hline \multirow[t]{2}{*}{ Residence } & -0.122 & -0.014 \\
\hline & $(0.165)$ & $(0.021)$ \\
\hline \multirow[t]{2}{*}{ Marital situation (Married) } & $-2.168^{\star \star \star}$ & $-0.284^{\star \star \star}$ \\
\hline & $(0.161)$ & $(0.021)$ \\
\hline \multicolumn{3}{|l|}{ Very poor } \\
\hline \multirow[t]{2}{*}{ Poor } & $0.375^{\star}$ & $0.186^{\star}$ \\
\hline & $(0.220)$ & $(0.122)$ \\
\hline \multirow[t]{2}{*}{ Less rich } & $0.378^{\star}$ & $0.202^{*}$ \\
\hline & $(0.203)$ & $(0.115)$ \\
\hline \multirow[t]{2}{*}{ Rich } & $0.581^{\star * *}$ & $0.316^{* * *}$ \\
\hline & $(0.192)$ & $(0.109)$ \\
\hline \multirow[t]{2}{*}{ More Rich } & $0.643^{\star * \star}$ & $0.326^{\star * *}$ \\
\hline & $(0.194)$ & $(0.109)$ \\
\hline \multirow[t]{2}{*}{ Household size } & $0.0691^{\star \star \star}$ & $0.009^{*}$ \\
\hline & $(0.0154)$ & $(0.002)$ \\
\hline \multirow[t]{2}{*}{ House-primary } & $-0.181^{\star *}$ & $-0.023^{\star * *}$ \\
\hline & $(0.0746)$ & $(0.010)$ \\
\hline \multirow[t]{2}{*}{ House-secondary } & 0.0532 & $0.006^{\star * *}$ \\
\hline & $(0.0637)$ & $(0.008)$ \\
\hline \multirow[t]{2}{*}{ Land possession } & $-0.288^{\star *}$ & $-0.036^{\star * *}$ \\
\hline & $(0.121)$ & $(0.016)$ \\
\hline \multirow[t]{2}{*}{ Electricity Possession } & 0.172 & 0.022 \\
\hline & $(0.137)$ & $(0.018)$ \\
\hline \multirow[t]{2}{*}{ Constant } & $7.993^{\star * *}$ & $1.043^{* * *}$ \\
\hline & $(0.449)$ & $(0.078)$ \\
\hline Observations & 5.321 & 5.321 \\
\hline
\end{tabular}

Source: Author's calculation from QUIBB 2015 survey data. 
Table 4. Men's versus women's education estimation.

\begin{tabular}{|c|c|c|}
\hline VARIABLES & $\begin{array}{c}\text { (1) } \\
\text { Marginal effects on male } \\
\text { education }\end{array}$ & $\begin{array}{l}\text { (2) } \\
\text { Marginal effects on } \\
\text { femaleeducation }\end{array}$ \\
\hline \multirow[t]{2}{*}{ Migrant Transfer } & $-0.268^{\star \star}$ & -0.00351 \\
\hline & $(0.121)$ & $(0.00433)$ \\
\hline \multirow[t]{2}{*}{ Age } & $-0.177^{\star \star \star}$ & $-0.0113^{\star * *}$ \\
\hline & $(0.0393)$ & $(0.00167)$ \\
\hline \multirow[t]{2}{*}{ age2 } & 0.00117 & $9.87 e-05^{\star * *}$ \\
\hline & $(0.000938)$ & $(1.69 \mathrm{e}-05)$ \\
\hline \multirow[t]{2}{*}{ Residence } & $-1.122^{\star \star \star *}$ & $0.0198^{\star * *}$ \\
\hline & $(0.0745)$ & $(0.00538)$ \\
\hline \multirow[t]{2}{*}{ Marital situation } & $-1.259^{* * *}$ & $-0.0347^{\star * *}$ \\
\hline & $(0.131)$ & $(0.00526)$ \\
\hline \multirow[t]{2}{*}{ Poor } & $2.1372^{* * *}$ & $0.00689^{* * *}$ \\
\hline & $(0.2610)$ & $(0.00150)$ \\
\hline \multirow[t]{2}{*}{ Less rich } & $2.0415^{\star * *}$ & $1.1415^{* * *}$ \\
\hline & $(0.24908)$ & $(0.34908)$ \\
\hline \multirow[t]{2}{*}{ Rich } & $2.4464^{* * *}$ & $2.3464^{* * *}$ \\
\hline & $(.249606)$ & $(0.1496)$ \\
\hline \multirow[t]{2}{*}{ More Rich } & $2.0208^{\star * *}$ & $2.0208^{* * *}$ \\
\hline & $(0.22329)$ & $(0.1523)$ \\
\hline \multirow[t]{2}{*}{ Houshold size } & $0.0431^{\star * *}$ & $0.00319^{* * *}$ \\
\hline & $(0.00854)$ & $(0.000583)$ \\
\hline \multirow[t]{2}{*}{ Home-primary distance } & $0.388^{\star * *}$ & $-0.00881^{\star \star \star}$ \\
\hline & $(0.0466)$ & $(0.00238)$ \\
\hline \multirow[t]{2}{*}{ Home-secondary distance } & $0.199^{* * *}$ & $-0.00789^{* * *}$ \\
\hline & $(0.0312)$ & $(0.00173)$ \\
\hline \multirow[t]{2}{*}{ House possession } & $-1.118^{\star * *}$ & 0.00311 \\
\hline & $(0.0689)$ & $(0.00334)$ \\
\hline \multirow[t]{2}{*}{ Electricity possession } & $0.345^{\star * *}$ & -0.00184 \\
\hline & $(0.0496)$ & $(0.00392)$ \\
\hline \multirow[t]{2}{*}{ Constant } & $3.523^{* * *}$ & $0.168^{\star * *}$ \\
\hline & $(0.458)$ & $(0.0250)$ \\
\hline Observations & 11.739 & 5.962 \\
\hline
\end{tabular}

Robust standard errors in parentheses. Shows significance: ${ }^{* *} p<0.01,{ }^{* *} p<0.05,{ }^{\star} p<$ 0.1. Source: Author's calculation from QUIBB 2015 survey data. 
probit model. The results obtained by the probit regression seem to confirm those previously obtained through the logit regression.

As a reminder, the instrumental variables that we had used in the context of this research to remove the problem of endogeneity of the variable of interest transfers of migrants are three in number: the number of children of all adult members except those of the head of household, expenses for family events and investments in real estate.

The validity test of the instruments allowed us to select two of them, including the number of children of all adult members and the expenses for family events. The investment in real estate being rejected as an instrument must either be removed from the estimate or integrated as a control variable in the equation of interest. Moreover, the overidentification test does not reject the hypothesis of significance of the two instruments used. The results of the estimates with instrumental variables show us that the interest variable "migrant remittances" increases the probability of significantly increasing one's human capital. The results of these estimates confirm the conclusions of the work of Bouoiyour et al. (2018) who find by analyzing the relationship between migrant remittances and the education of Moroccan children, that the level of education achieved increases significantly with remittances when we remove the problem of endogeneity of remittances by the method of instrumental variables.

Variables such as age, marital status, homeownership decrease the likelihood of increasing one's level of education. The negative sign of this last variable remains a counterintuitive result since owning a house allows the individual to have less concern for housing and therefore allows him to focus his efforts on education.

Through probit regression, funds received from migrants, gender of the head of household, wealth quintile, homeownership and electricity possession increase the probability of increasing the level of education significantly except for homeownership which remains insignificant.

With regard to household size, the results of the estimates show that it increases the probability of lengthening the level of education. Results remain counterintuitive given that in Africa and particularly in Togo the size of the household is a limiting factor in schooling given the high number of people in households and the difficulties in taking care of the education expenses of the latter.

As we have several instruments, it is likely to face a problem of overidentification. We then have to go through an overidentification test. We must verify that the residue of the reestimated equation is not correlated with our instruments. This is equivalent to testing the overall nullity of the regression coefficients by including the residuals. The null hypothesis (H0) will be accepted if the calculated statistic $\left(\mathrm{N}^{*} \mathrm{R}^{2}\right)$ has a value lower than the theoretical value (Table 5).

\section{Conclusion}

This article analyzed the effect of migrant remittances on the education of recipient 
Table 5. Logit, Probit estimation and Instrumental Variable Results.

\begin{tabular}{|c|c|c|c|}
\hline VARIABLES & $\begin{array}{l}(1) \\
\text { Logit regression }\end{array}$ & $\begin{array}{l}(2) \\
\text { Probit regression }\end{array}$ & $\begin{array}{c}\text { (3) } \\
\text { Estimation by } \\
\text { instrumental variables }\end{array}$ \\
\hline \multirow[t]{2}{*}{ Migrant transfer } & 0.129 & 0.0570 & $2.594^{*}$ \\
\hline & $(0.229)$ & $(0.119)$ & $(1.405)$ \\
\hline \multirow[t]{2}{*}{ Age } & $-0.473^{* * *}$ & $-0.263^{* * *}$ & $-0.077^{\star * *}$ \\
\hline & $(0.0184)$ & $(0.0101)$ & $(0.005)$ \\
\hline \multirow[t]{2}{*}{ Age 2} & $0.00394^{\star * \star}$ & $0.00228^{\star * *}$ & $0.001^{\star * *}$ \\
\hline & $(0.000204)$ & $(0.000127)$ & $(0.0002)$ \\
\hline \multirow[t]{2}{*}{ Sex } & $0.535^{\star * *}$ & $0.282^{\star * *}$ & $0.395^{\star * \star}$ \\
\hline & $(0.108)$ & $(0.0586)$ & $(0.030)$ \\
\hline \multirow[t]{2}{*}{ Residence } & -0.122 & -0.0826 & 0.010 \\
\hline & $(0.165)$ & $(0.0880)$ & $(0.052)$ \\
\hline \multirow[t]{2}{*}{ Marital situation } & $-2.168^{\star * *}$ & $-1.183^{* * *}$ & $-0.091^{\star * *}$ \\
\hline & $(0.161)$ & $(0.0831)$ & $(0.029)$ \\
\hline \multirow[t]{2}{*}{ Poor } & $0.375^{*}$ & 0.186 & $0.21939^{\star * *}$ \\
\hline & $(0.220)$ & $(0.122)$ & $(0.0256)$ \\
\hline \multirow[t]{2}{*}{ Less rich } & $0.378^{*}$ & $0.202^{*}$ & $0.1844^{\star * *}$ \\
\hline & $(0.203)$ & $(0.115)$ & $(.03003)$ \\
\hline \multirow[t]{2}{*}{ Rich } & $0.581^{\star * *}$ & $0.316^{\star * *}$ & $0.2433^{\star * *}$ \\
\hline & $(0.192)$ & $(0.109)$ & $(0.02984)$ \\
\hline \multirow[t]{2}{*}{ More rich } & $0.643^{\star * *}$ & $0.326^{\star * *}$ & $0.1995^{\star * \star}$ \\
\hline & $(0.194)$ & $(0.109)$ & 0.037894 \\
\hline \multirow[t]{2}{*}{ Household size } & $0.0691^{\star \star \star}$ & $0.0393^{* * *}$ & 0.008 \\
\hline & $(0.0154)$ & $(0.00835)$ & $(0.005)$ \\
\hline \multirow[t]{2}{*}{ House-primary } & $-0.181^{\star *}$ & $-0.103^{\star *}$ & $-0.067^{\star * *}$ \\
\hline & $(0.0746)$ & $(0.0411)$ & $(0.012)$ \\
\hline \multirow[t]{2}{*}{ House-secondary } & 0.0532 & 0.0336 & -0.009 \\
\hline & $(0.0637)$ & $(0.0355)$ & $(0.025)$ \\
\hline \multirow[t]{2}{*}{ House possession } & $-0.288^{\star *}$ & $-0.154^{\star *}$ & 0.014 \\
\hline & $(0.121)$ & $(0.0666)$ & $(0.025)$ \\
\hline \multirow[t]{2}{*}{ Electricity possession } & 0.172 & 0.0942 & 0.026 \\
\hline & $(0.137)$ & $(0.0735)$ & $(0.027)$ \\
\hline \multirow[t]{2}{*}{ Constant } & $7.993^{\star * *}$ & $4.433^{\star * \star}$ & 1.425 \\
\hline & $(0.449)$ & $(0.244)$ & $(0.154)$ \\
\hline Observations & 5.321 & 5.321 & 5.321 \\
\hline
\end{tabular}

Robust standard errors in parentheses; ${ }^{* *} p<0.01,{ }^{* *} p<0.05,{ }^{\star} p<0.1$. Source: Author's calculation from QUIBB 2015 survey data 
households in Togo using data from the 2015 QUIBB survey. The main result of this study was that the remittances that households receive from migrants contribute to a significant improvement in their level of education. Our results also showed that these transfers do not impact the education of a girl and a boy in the same way. However, a comparative analysis of the effect of these transfers shows that remittances seem to encourage boys to step back from education, unlike girls. Similarly, our results suggest that living a long distance from primary school reduces a child's incentive to attend in order to increase their human capital. The results of this research provide a new perspective on migrant remittances with more recent data to complement the qualitative aspect of recipients not taken into account by the work already done.

However, without questioning the results of our research, we recognize certain limitations that are related to the data of the QUIBB 2015 survey that we are presenting in this section. This research can be dealt with in a different way if we have qualitative information on the reasons why some family members are not in school.

\section{Conflicts of Interest}

The authors declare no conflicts of interest regarding the publication of this paper.

\section{References}

Acosta, P. (2006). Labor Supply, School Attendance, and Remittances from International Migration: The Case of El Salvador. World Bank Policy Research Working Paper, 3903. https://doi.org/10.1596/1813-9450-3903

Adams, R. H., \& Cuecuecha, A. (2010). Remittances, Household Expenditure and Investment in Guatemala. World Development, 38, 1626-1641. https://doi.org/10.1016/j.worlddev.2010.03.003

Agarwal, R., \& Horowitz, A. W. (2002). Are International Remittances Altruism or Insurance? Evidence from Guyana Using Multiple-Migrant Households. World Development, 30, 2033-2044. https://doi.org/10.1016/S0305-750X(02)00118-3

Amemiya, T. (1981). Qualitative Response Models: A Survey. Journal of Economic Literature, $19,1483-1359$.

Amuedo-Dorantes, C., Pozo, S., Oettinger, G., Trejo, S., Lucas, B., \& Blank, R. (2006). Migration, Remittances, and Male and Female Employment Patterns. American Economic Review, 96, 222-226. https://doi.org/10.1257/000282806777211946

Askarov, Z., \& Doucouliagos, H. (2020). A Meta-Analysis of the Effects of Remittances on Household Education Expenditure. World Development, 129, Article ID: 104860. https://doi.org/10.1016/j.worlddev.2019.104860

Ballo, Z., \& Alphonsine, C. (2018). Migrants' Remittances as a Source of Funding Local Development: Case of Burkinabè Migrants in Côte d'Ivoire. Theoretical Economics Letters, 8, 1412-1426. https://doi.org/10.4236/tel.2018.87091

Bouoiyour, J., \& Miftah, A. (2014). Munich Personal RePEc Archive Education, Gender and Remittances: What Interactions in Rural Morocco? Education, Genre et Transferts de fonds des migrants Quelles interactions dans le Maroc rural? University Library of 
Munich, Munich.

Bouoiyour, J., Miftah, A., Bouoiyour, J., Miftah, A., De, T., \& Une, M. (2018). Transferts de fonds, éducation et travail des enfants au Maroc. Une analyse par score de propension. Centre d'Analyse Théorique et de Traitement des données économiques, HAL ID: hal-01880343

Boutin, D. (2011). Envoi de fonds et allocation du temps des enfants au Niger: L'effet indirect des chocs négatifs 1-36.

Calero, C., Bedi, A. S., \& Sparrow, R. (2009). Remittances, Liquidity Constraints and Human Capital Investments in Ecuador. World Development, 37, 1143-1154. https://doi.org/10.1016/j.worlddev.2008.10.006

Chea, V., \& Wongboonsin, P. (2020). Do Remittances Increase Household Investment in Education? Evidence from Cambodia during and after the Global Financial Crisis. Journal of Population and Social Studies, 28, 1-21. https://doi.org/10.25133/JPSSv28n1.001

Cimmyt (1993). The Adoption of Agricultural Technology: A Guide for Survey Design. Economics Program, International Maize, et Wheat Improvement Center.

de Haas, H. (2006). Migration, Remittances and Regional Development in Southern Morocco. Geoforum, 37, 565- 580. https://doi.org/10.1016/j.geoforum.2005.11.007

De Vreyer, P., Gubert, F., \& Robilliard, A. S. (2010). Are There Returns to Migration Experience? An Empirical Analysis Using Data on Return Migrants and Non-Migrants in West Africa. Annals of Economics and Statistics, 307-328. https://doi.org/10.2307/41219120

Gang, M., Zhu, X. Y., Fang, L., Shan, L., Ren, C., \& Wen, H. H. (2008). Nodal Gap in Fe-Based Layered Superconductor $\mathrm{LaO}_{0.9} \mathrm{~F}_{0.1-\delta}$ FeAs Probed by Specific Heat Measurements. Chinese Physics Letters, 25, 2221-2224. https://doi.org/10.1088/0256-307X/25/6/082

García Nájera, Y., \& Cuecuecha Mendoza, A. (2020). The Impact of International Remittances on Investment in Education in Caltimacán, Hidalgo. Migraciones internacionales, 11, 1-25.

Gertler, P., \& Glewwe, P. (1989). The Willingness to Pay for Education in Developing Countries: Evidence from Rural Peru. Working Paper No. 54, Living Standards Measurement Study.

Gouriéroux, C., \& Monfort, A. (1989). Statistique et modèles économétriques: Notions générales, estimation, prévision, algorithmes. Dunod.

Gubert, F. (2002). Do Migrants Insure Those Who Stay Behind? Evidence from the Kayes Area (Western Mali). Oxford Development Studies, 30, 267-287. https://doi.org/10.1080/1360081022000012699

Hanson, G. H., \& Woodruff, C. (2003). Emigration and Educational Attainment in Mexico. University of California at San Diego, Mimeographed, 39.

López-Córdova, E., \& Olmedo, A. (2006). International Remittances and Development: Existing Evidence, Policies and Recommendations. Occasional Paper, Inter-American Development Bank.

Maddala, G. (1983). Methods of Estimation for Models of Markets with Bounded Price Variation. International Economic Review, 24, 361-378. https://doi.org/10.2307/2648751

Mansour, W., Chaaban, J., \& Litchfield, J. (2011). The Impact of Migrant Remittances on School Attendance and Education Attainment: Evidence from Jordan. International 
Migration Review, 45, 812-851. https://doi.org/10.1111/j.1747-7379.2011.00869.x

Mansuri, G. (2006). Migration, School Attainment and Child Labor: Evidence from Rural Pakistan. Policy Research Working Paper No. 3945, World Bank. https://doi.org/10.1596/1813-9450-3945

Matano, A., \& Ramos, R. (2013). Remittances and Educational Outcomes: Evidence for Moldova. AQR Research Group-IREA, Universitat de Barcelona, http://www.ub.edu/searchproject/wp-content/uploads/2013/05/SEARCH-WP-3.10.pdf

Mckenzie, D., \& Rapoport, H. (2006). Can Migration Reduce Educational Attainment? Policy Research Working Paper No. 3952, World Bank. https://doi.org/10.1596/1813-9450-3952

Mckenzie, D., Bollard, A., Morten, C. M., \& Rapoport, H. (2011). Remittances and the Brain Drain Revisited: The Microdata Show That More Educated Migrants Remit More. The World Bank Economic Review, 25, 132-156. https://academic.oup.com https://doi.org/10.1093/wber/lhr013

Medina, C., \& Cardona, L. (2010). The Effects of Remittances on Household Consumption, Education Attendance and Living Standards: The Case of Colombia. Lecturas de Economía, 72, 11-44.

Pickbourn, L. (2016). Remittances and Household Expenditures on Education in Ghana's Northern Region: Why Gender Matters. Feminist Economics, 22, 74-100. https://doi.org/10.1080/13545701.2015.1107681

Rapoport, H., \& Docquier, F. (2005). The Economics of Migrants' Remittances. SSRN. https://doi.org/10.2139/ssrn.690144

Raut, N. K., \& Tanaka, R. (2018). Parental Absence, Remittances and Educational Investment in Children Left Behind: Evidence from Nepal. Review of Development Economics, 22, 1642-1666. https://doi.org/10.1111/rode.12410

Rivers, D., \& Vuong, Q. H. (1988). Limited Information Estimators and Exogeneity Tests for Simultaneous Probit Models. Journal of Econometrics, 39, 347-366.

https://doi.org/10.1016/0304-4076(88)90063-2

UNESCO (2020). https://en.unesco.org/

Woodruff, C., \& Zenteno, R. (2001). Remittances and Microenterprises in Mexico. Working Paper, Graduate School of International Relations and Pacific Studies. https://doi.org/10.2139/ssrn.282019

World Bank (2020). The World Bank Annual Report 2020. World Bank Publications.

Yang, D. (2008). International Migration, Remittances and Household Investment: Evidence from Philippine Migrants' Exchange Rate Shocks. Economic Journal, 118, 591-630. https://doi.org/10.1111/j.1468-0297.2008.02134.x 


\section{Annex}

Table A1. Instrument overidentification test.

\begin{tabular}{cccc}
\hline Sargan $\mathrm{N}^{*} \mathrm{R}$-sq test & 0.4515 & Chi-sq $(2)$ & $p$-value $=0.4878$ \\
Basmann test & 0.4408 & Chi-sq (2) & $p$-value $=0.4704$ \\
\hline
\end{tabular}

Source: Author's calculation from QUIBB 2015 survey data.

Table A2. Causality test between instrumental variables and the error term.

\begin{tabular}{|c|c|c|c|c|c|}
\hline Education & Coef, & $p$-value & {$[95 \%$} & Interval] & Sig \\
\hline Migrant transfer & 1.49 & 0.000 & 0.000 & 0.000 & $* * *$ \\
\hline Residue & 0.000 & 0.000 & 0.000 & 0.000 & $* * *$ \\
\hline Residence & -0.082 & 0.280 & -0.231 & 0.067 & \\
\hline Age & 0.001 & 0.263 & -0.001 & 0.004 & \\
\hline Size & 0.010 & 0.276 & -0.008 & 0.029 & \\
\hline Sex & -0.166 & 0.000 & -0.248 & -0.084 & $* * *$ \\
\hline House Possession & 0.117 & 0.030 & 0.012 & 0.223 & ** \\
\hline Electricity Possession & -0.384 & 0.000 & -0.513 & -0.256 & $* * *$ \\
\hline Piped water & -0.249 & 0.011 & -0.441 & -0.056 & $* *$ \\
\hline Internal water & -0.061 & 0.517 & -0.247 & 0.124 & \\
\hline Distance (House-road) & -0.039 & 0.180 & -0.096 & 0.018 & \\
\hline Time (House-market) & -0.038 & 0.065 & -0.079 & 0.002 & * \\
\hline Constant & 0.719 & 0.000 & 0.461 & 0.977 & $* * *$ \\
\hline Mean dependent var & 0.098 & \multicolumn{3}{|c|}{ SD dependent var } & \\
\hline R-squared & 0.505 & \multicolumn{3}{|c|}{ Number of obs } & 000 \\
\hline F-test & 82.652 & \multicolumn{3}{|c|}{ Prob $>$ F } & \\
\hline Akaike crit. (AIC) & -795.340 & \multicolumn{3}{|c|}{ Bayesian crit. (BIC) } & 043 \\
\hline
\end{tabular}

${ }^{* *} p<0.01,{ }^{* *} p<0.05,{ }^{*} p<0.1$. Source: Author's calculation from QUIBB 2015 survey data. 